\title{
Efektivitas Dan Pengaruh Model Pembelajaran Inkuiri Pada Pembelajaran IPA Di SDN 1 Aikmual Tahun 2019
}

\author{
Asrorul Azizi $^{1,}$ Mulia Rasyidi $^{2}$ \\ ${ }^{1}$ Program studi Pendidikan guru Pendidikan Anak Usia Dini \\ ${ }^{2}$ Program Studi Pendidikan Ilmu Pengetahuan Alam \\ asroruljilid3@gmail.com mulia.rasyidi@gmail.com
}

\begin{abstract}
Abstrak . Tujuan Penelitian ini adalah untuk mengetahui tingkat efektivitas dan pengaruh pembelajaran inkuiri dengan disertai metode eksperimen pada pelajaran IPA di SDN 1 Aikmual. Metode penelitian yang digunakan adalah One Group pre-tes post-test Design. Jumlah siswa yang diteliti adalah 25 orang. Instrumen yang digunakan meliputi dua aspek yaitu kemampuan kognitif dan keterampilan proses sains (KPS) siswa. Hasil penelitian menunjukkan bahwa pembelajaran inkuiri termasuk ke dalam tingkat efektif sedang dan terdapat perbedaan signifikan antara sebelum dan sesudah belajar dengan model pembelajaran inkuiri pada kedua aspek yang diteliti.
\end{abstract}

Kata kunci: Model Inkuiri, Kemampuan Kognitif, Dan Kemampuan Proses Sains.

Abstract. This purpose of this study want to know how the effectiveness and the effect inquire learning with experiment method in science lesson at SDN 1 Aikmual. The methodology in this study use a One Group pre-test post-test design. Participant on this study isi 25 students. The instrument had a two aspect that is cognitive ability and science process skills. The result showed that inquire learning in this study has a medium efective and show the significant between before and after using the inquire learning in the two aspect in this study.

\section{Keywords: Inquire Learning, Cognitive Ability And Science Process Skills.}

\section{PENDAHULUAN}

Ilmu Pengetahuan Alam (IPA) berhubungan dengan cara kita mengetahui yang berkaitan dengan alam secara sistematis, oleh karena itu, belajar IPA bukan hanya penguasaan teori yang berupa fakta-fakta, konsep-konsep, atau prinsip-prinsip saja tetapi juga merupakan suatu proses menemukan. Pada proses pembelajaran IPA diharapkan dapat menjadi wahana bagi siswa untuk mempelajari diri sendiri dan alam sekitar serta prospek pengembangan lebih lanjut dalam menerapkannya dalam kehidupan sehari-hari (Depdiknas, 2006).

Pendidikan di Indonesia telah memperkanalkan pembelajara IPA pada siswa semenjak Sekolah Dasar (SD), karena IPA merupakan pelajaran yang pasti berkaitan erat dengan kehidupan peserta didik, bahkan Putri (2014) menyatakan dengan tegas bahwa belajar melalui IPA diharapkan dapat membentuk karakter yang positif pada diri peserta didik sehingga kelak akan menjadi individu yang lebih bijaksana dalam menyikapi permasalahan- permasalahan lingkungan maupun sosial. Pendidikan IPA sudah dimulai dari SD, hendaknya membuat para siswa di Indonesia dapat bersaing dengan negara-negara lain. Akan tetapi, hal tersebut tidak bisa sesuai dengan yang diharapkan. Pada kenyataannya beberapa riset yang dilakukan oleh pusat statistik Internasional menunjukan hasil yang kurang memuaskan dari kemampuan siswa di Indonesia di bidang IPA.

Hasil temuan yang dilaporkan Programme for International Student Assessment (PISA) tahun 2009, bahwa peringkat Indonesia baru bisa menduduki 10 besar terbawah dari 65 negara; Membaca urutan ke-57, Matematika urutan ke-61 dan IPA urutan ke-60 (Elianur, p. 2011). Berdasarkan laporanlembaga internasional yang berkenaan dengan tingkat sumber daya manusia dan pendidikan dunia. Seperti laporan Trends International in 
Matemathics and Science Study (TIMSS), bahwa pada tahun 2003, Indonesia berada pada urutan ke-36 dari 45 negara peserta baik pada bidang matematika maupun bidang sains (Puskur, p. 2007). Melalui hasil laporan tersebut maka kemampuan yang diharapkan dari pelajaran IPA yang terjadi di Indonesia tidak sesuai dengan apa yang dicita-citakan. Kita selalu berada pada rangking yang rendah diantara negara-negara lain. Bahkan dengan sesama negara ASEAN. Rendahnya nilai kemampuan IPA Indonesia menurut Wuryastuti (2008) dikarenakan 1) Dalam proses belajar mengajar di sekolah saat ini tidak atau belum memberi kesempatan maksimal kepada siswa untuk mengembangkan kreatiftasnya, lebih mengutamakan pada kemampuan menghafal; 2) Kurang kontekstual dengan kehidupan siswa sehari-hari; 3) Keterampilan proses belum nampak dalam pembelajaran di sekolah dengan alasan untuk mengejar target kurikulum; dan 4) Pelajaran IPA yang konvensional hanya menyiapkan peserta didik untuk melanjutkan studi yang lebih tinggi, bukan menyiapkan SDM yang dibutuhkan oleh masyarakat. Hal ini sejalan dengan penelitian yang dilakukan oleh Susilawati (2010), Hana (2009) dan Fahrizal (2009) dalam Ismail (2011) yang mengungkapkan bahwa kamampuan kognitif dan keterampilan proses sains siswa rendah ketika di terapkan model pembelajaran secara konvensional (ceramah) yang lebih mengutamakan kemampuan kognitif saja.

Rustaman (2005) menyatakan bahwa sistem pendidikan yang terlalu menekankan pada kognitif ini juga terlalu abstrak (tidak konkrit), dengan proses pembelajaran yang pasif, kaku, sehingga proses belajar menjadi sangat tidak menyenangkan dan penuh beban. Semua ini telah "membunuh" karakter, siswa menjadi tidak kreatif, tidak percaya diri, tertekan dan stress, serta tidak mencintai belajar.

Salah satu metode pembelajaran yang dianggap mampu meningkatkan kemampuan IPA baik berupa konsep maupun keterampilan proses sains siswa adalah metode eksperimen. Metode ini dapat membuat siswa terlibat secara langsung dalam proses pembelajaran. Mereka dapat melakukan percobaan, mengamati sesuatu, menganalisis, membuktikan dan menarik kesimpulan sendiri tentang suatu objek/keadaan. Metode eksperimen paling tepat untuk merealisasikan pembelajaran dengan inkuiri atau penemuan. Eksperimen dapat dilakukan di dalam laboratorium atau di luar laboratorium, dan pekerjaan eksperimen mengandung makna belajar untuk berbuat, karena itu dapat dimasukkan dalam metode pembelajaran (Rustaman, et al. 2005). Pernyataan tersebut didukung oleh penelitian yang dilakukan oleh (Dhewi, 2005) dia mengungkapkan bahwa metode eksperimen lebih efektif meningkatkan pemahaman siswa dibandingkan dengan metode konvensional.

Menurut Adisyahputra (1992) dengan menggunakan metode eksperimen siswa dilatih untuk menggunakan metode ilmiah dan sikap ilmiah secara benar dan sesungguhnya. Siswa dilatih untuk membaca data secara objektif menurut apa adanya, mengambil kesimpulan hanya berdasarkan fakta-fakta yang cukup mendukung, menyadari keterbatasan IPA, keterbatasan ketelitian suatu pengukuran, keterbatasan suatu hukum atau teori, memahami makna dari suatu teori dan sebaginya. Hal-hal semacam ini sukar untuk dimengerti hanya dengan cara mendengarkan melalui ceramah. Inkuiri merupakan model yang disarankan oleh Depdiknas (2006) karena dapat menumbuhkan kemampuan berpikir, bekerja dan bersikap ilmiah serta mengkomunikasikannya sebagai aspek penting kecakapan hidup. Oleh karena itu pembelajaran IPA di SD/MI menekankan pada pemberian pengalaman belajar secara langsung melalui penggunaan dan pengembangan keterampilan proses dan sikap ilmiah, sehingga Pembelajaran inkuiri dengan menggunakan metode eksperimen diprediksi mampumemfasilitasi peningkatan kemampuan kognitif dan keterampilan proses sains siswa.

Menurut Gulo (2002), inkuiri berarti suatu rangkaian kegiatan belajar yang 
melibatkan secara maksimal keseluruhan kemampuan siswa dalam mencari dan menyelidiki secara sistematis, kritis, logis, analitis, sehingga mereka dapat merumuskan sendiri penemuannya dengan penuh percaya diri. Dengan model pembelajaran inkuiri, materi pelajaran yang didapatkan siswa akan lebih tahan lama, mudah diingat, lebih mudah diaplikasikan pada kondisi yang berbeda, dapat memunculkan motivasi belajar, dapat melatih kecakapan berpikir secara terbuka, dapat meningkatkan penguasaan konsep, mengembangkan sikap ilmiah, dapat mengembangkan pemahaman siswa yang mendalam tentang konsep sains dan juga dapat mengembangkan keterampilan berpikir kritis (Bruner dalam Dahar, p. 1989).

Berdasarkan pemaparan di atas, maka dapat dikatakan bahwa model pembelajaran inkuiri dan metode eksperimen diperkirakan mampu meningkatkan kemampuan kognitif siswa dan melatihkan serta mengembangkan keterampilan proses sains siswa.

\section{METODE PENELITIAN}

Penelitian ini dilaksanakan di SDN 1 Aikmual Kecamatan Praya pada semeter ganjil tahun pelajaran 2018/2019. Metode penelitian yang digunakan dalam penelitian ini ialah metode eksperimensemu (quasi experiment). Metode ini memiliki karakteristik yaitu mengkaji keadaan praktis suatu objek, yang didalamnya tidak mungkin untuk mengontrol semua variabel yang relevan kecuali variabel-variabel yang diteliti (Panggabean, 1996). Metode ini dipandang cocok untuk penelitian pendidikan, mengingat banyak faktor yang diprediksi berpengaruh terhadap hasil penelitian yang tidak dapat atau sulit untuk dikontrol .

Desain penelitian yang digunakan adalah One Group pre-tes post-test Design, yaitu penelitian eksperimen yang dilaksanakan pada satu kelompok saja, yang dinamakan kelompok eksperimen tanpa ada kelompok pembanding atau kelompok kontrol. Sebelum diberi perlakuan, sampel penelitian dites yang disebut pretes. Begitupun setelah diberi perlakuan sampel penelitian dites lagi dan disebut dengan postes. Tes yang diberikan sebelum dan sesudah perlakuan ditujukan untuk mengetahui hasil belajar siswa pada ranah kognitif. Perbedaan antara hasil pengukuran awal (T1) dengan hasil pengukuran akhir (T2) adalah merupakan pengaruh dari perlakuan yang diberikan. Skema disain penelitian yang digunakan dapat digambarkan sebagai berikut:

Tabel 1. Tabel desain penelitian One Group Pre-test, post-test Design

\begin{tabular}{|c|c|c|c|}
\hline Kelompok & $\begin{array}{l}\text { Pre } \\
\text { test }\end{array}$ & $\begin{array}{l}\text { Treatme } \\
\text { nt }\end{array}$ & $\begin{array}{l}\text { Post } \\
\text { tes }\end{array}$ \\
\hline $\begin{array}{c}\text { eksperime } \\
n\end{array}$ & $T_{1}$ & $X$ & $T_{1}$ \\
\hline
\end{tabular}

(Sumber: Panggabean,1996) Keterangan:

T1 : Pre Test (test awal)

$X$ : Perlakuan terhadap kelompok ksperimen yaitu dengan menerapkan model inkuiri dan metode eksperimen.

T1' : Post Test (test akhir)

Populasi dalam penelitian ini adalah siswa kelas VI di SDN 1 Aikmual. Data pengaruh dan kefektifan siswa baik kemampuan kognitif dan keterampilan proses sains dilihat melalui pretes dan postes dengan menggunakan instrumen tes pilihan ganda sejumlah 40 soal. Kemampuan kognitif sebanyak 22 soal dan keterampilan proses sains sebanyak 18 soal.

Pengaruh dalam penelitian ini diuji menggunakan program statistik mini tab 16 dengan menghitung uji hipotesis hasil pretes dan postes. Namun, sebelum diuji hipotesisnya kedua data tersebut (pretes dan postes). harus melalui uji normalitas dan homogenitas sebagai prasyarat uji analisis selanjutnya. Jika data yang diuji terdistribusi normal dan memiliki homogenitas varian yang sama, maka pengujian hipotesis dilakukan dengan analisis statistik parametrik dengan menggunakan Anova. Jika tidak, analisis pengujian dilakukan dengan analisis statistik non parametrik menggunakan uji Mann-Whitney.

Efektivitas pembelajaran IPA dapat diketahui dengan cara menghitung gain skor yang ternormalisasi $\langle\mathrm{g}\rangle$. Langkah- langkah 
yang ditempuh dalam melihat efektivitas pembelajaran adalah sebagai berikut:

a. Menghitung gain skor ternormalisasi dan menjumlahkan nilai gain ternormalisasi untuk seluruh siswa menggunakan rumus:

$<g>=\frac{T-T_{i}}{S I-T}$

dimana: $\langle\mathrm{g}\rangle=$ gain ternormalisasi $\mathrm{Tf}=$ skor posttest;

$\mathrm{Ti}=$ skor pretest $; \mathrm{SI}=$ skor ideal

b. Menentukan nilai rata-rata dari skor gain ternormalisasi

c. Menentukan kriteria efektivitas pembelajaran pada standar berikut ini:

\section{Tabel 2. Kriteria Efektivitas}

\section{Pembelajaran}

\begin{tabular}{|l|l|}
\hline Persentase & Efektivitas \\
\hline $0,00<\mathrm{h} \leq 0,30$ & Rendah \\
\hline $0,30<\mathrm{h} \leq 0,70$ & Sedang \\
\hline $0,70<\mathrm{h} \leq 1,00$ & Tinggi \\
\hline
\end{tabular}

\section{HASIL}

Hasil penelitian dan pembahasan mengenai efektivitas dan pengaruh pembelajaran inkuiri dengan menggunakan metode eksperimen dibagi menjadi dua yaitu 1) Kemampuan kognitif dan 2) Keterampilan proses sains.

\section{Kemampuan Kognitif}

\section{Efektivitas Pembelajaran Inkuiri}

Kemampuan kognitif siswa didapatkan dari skor tes pretes dan postes berupa pilihan ganda. Setelah didapatkan kedua skor tersebut maka didapatkan tingkat kefektifan model dengan menggunakan perhitungan gain yang dinormalisasi (Ngain). Skor pretes, postes, dan $N$-gain dapat dilihat pada Tabel 3.

Tabel 3. Skor Rata-Rata Post tes, Pretes dan N-gain Kemampuan Kognitif

\begin{tabular}{|c|l|l|}
\hline Pretest & Postes & N-gain \\
\hline 56 & 72, & 0,38 \\
& 9 & \\
\hline
\end{tabular}

Berdasarkan hasil skor pretes dan postes didapatkan skor rata-rata pretes sebesar 56 dan skor rata-rata posttes sebesar 72,9. Kemudian dari kedua rata-rata tersebut dihitung $\mathrm{N}$-gain yang didapatkan sebesar 0,38 atau dapat dikatakan bahwa pembelajaran menggunakan model inkuiri.terhadap kemampuan kognitif termasuk ke dalam kriteria efektif kategori sedang..

\section{Pengaruh Pembelajaran Inkuiri}

Pengaruh pembelajaran inkuiri dilakukan dengan menggunakan perhitungan statistik. Perhitungan statistik ini berguna untuk mengetahui apakah pengaruh dari pembelajaran model inkuiri tersebut signifikan atau tidak melalui perbandingan antara skor pretes dan postes. Pada Tabel 4 akan menampilkan hasil perhitungan uji normalitas, homogenitas, dan hipotesis kelas eksperimen. Tabel 4. Rekapitulasi Analisis Statistik serta Peninjauan Normalitas, Homogenitas, dan Hipotesis Kemampuan Kognitif

\begin{tabular}{|l|l|l|}
\hline $\begin{array}{l}\text { Komponen } \\
\text { peninjau }\end{array}$ & $\begin{array}{l}\text { Prete } \\
\text { s }\end{array}$ & $\begin{array}{l}\text { Poste } \\
\text { s }\end{array}$ \\
\hline Jumlah siswa & 25 & 25 \\
\hline Rata-rata & 56 & 72,8 \\
\hline $\begin{array}{l}\text { Uji normalitas (kolmogorov-Simirnov } \\
\text { test }) \text { P Value } \geq \alpha(\alpha=0,05)\end{array}$ \\
\hline Sig. & 0,816 & 0,064 \\
\hline interpretasi & Normal & $\begin{array}{l}\text { norm } \\
\text { al }\end{array}$ \\
\hline $\begin{array}{l}\text { Uji Homogenitas Berpasangan (Bartlett's } \\
\text { test) P Value } \geq \alpha(\alpha=0,05)\end{array}$ \\
\hline signifikansi & 0,859 \\
\hline Interpretasi & Homogen \\
\hline $\begin{array}{l}\text { Uji hipotesis parametrik Anova P } \\
\text { Value } \geq \alpha(\alpha=0,05)\end{array}$ \\
\hline signifikansi & 0,000 \\
\hline Interpretasi & $\begin{array}{l}\text { Berbeda } \\
\text { signifikan }\end{array}$ \\
\hline
\end{tabular}

Berdasarkan hasil perhitungan pada Tabel 4 didapatkan bahwa skor pretes dan postes kelas eksperimen tersebut sebaran skornya normal, kemudian hasil uji homogenitas menunjukkan bahwa skor pretes dan postes menunjukan kedua data tersebut adalah homogen. Sehingga untuk melakukan pengujian signifikansi menggunakan pengujian parametrik (Anova) berdasarkan hasil pengujian didapatkan nilai p-value (signifikansi) lebih kecil dari tingkat kepercayaan $95 \% \quad(0,05)$ yakni sebesar 0,0000 . Hal ini berarti pembelajaran inkuiri melalui model inkuiri dengan metode 
eksperimen signifikan untuk meningkatkan kemampuan kognitif siswa.

\section{Keterampilan Proses Sains (KPS)}

\section{Efektivitas Pembelajaran Inkuiri}

Sama dengan kemampuan kognitif, Keterampilan Proses Sains (KPS) siswa didapatkan dari skor tes pretes dan postes berupa pilihan ganda. Setelah didapatkan kedua skor tersebut maka didapatkan tingkat kefektifan model dengan menggunakan perhitungan gain yang dinormalisasi $(N$-gain $)$. Skor pretes, postes, dan $N$-gain dapat dilihat pada Tabel 5.

Tabel 5. Skor Rata-Rata Pretes, Postes, dan $N$-Gain KPS

\begin{tabular}{|c|c|c|}
\hline Pretest & Postes & N-gain \\
\hline 55,6 & 78,6 & 0,42 \\
\hline
\end{tabular}

Berdasarkan hasil skor pretes dan postes didapatkan skor rata-rata pretes sebesar 52,2 dan skor rata-rata posttes sebesar 72,7. Kemudian dari kedua rata-rata tersebut dihitung $N$-gain yang didapatkan sebesar 0,43 atau dapat dikatakan bahwa pembelajaran menggunakan model inkuiri terhadap KPS siswa termasuk ke dalam kriteria efektif kategori sedang.

\section{Pengaruh Pembelajaran Inkuiri}

Pengaruh pembelajaran inkuiri pada KPS siswa juga dilakukan dengan menggunakan perhitungan statistik. Perhitungan statistik ini berguna untuk mengetahui apakah pengaruh dari pembelajaran model inkuiri tersebut signifikan atau tidak melalui perbandingan antara skor pretes dan postes. Pada Tabel 6 akan menampilkan hasil perhitungan uji normalitas, homogenitas, dan hipotesis kelas eksperimen.

Tabel 6. Rekapitulasi Analisis Statistik Serta Peninjauan Normalitas, Homogenitas dan Hipotesis KPS.

\begin{tabular}{|l|l|l|}
\hline $\begin{array}{c}\text { Kompon } \\
\text { en } \\
\text { peninjau }\end{array}$ & Pretes & Postes \\
\hline $\begin{array}{c}\text { Jumlah } \\
\text { siswa }\end{array}$ & 25 & 25 \\
\hline Rata-rata & 56 & 72,8 \\
\hline $\begin{array}{l}\text { Uji normalitas (kolmogorov-Simirnov } \\
\text { test) P Value } \geq \alpha(\alpha=0,05)\end{array}$ \\
\hline Sig. & 0,083 & 0,012 \\
\hline interpreta & Normal & normal \\
\hline
\end{tabular}

\begin{tabular}{|l|l|}
\hline si & \\
\hline $\begin{array}{l}\text { Uji Homogenitas Berpasangan (Bartlett's } \\
\text { test) P Value } \geq \alpha(\alpha=0,05)\end{array}$ \\
\hline $\begin{array}{l}\text { signifika } \\
\text { nsi }\end{array}$ & 0,0414 \\
\hline $\begin{array}{l}\text { Interpreta } \\
\text { si }\end{array}$ & Homogen \\
\hline $\begin{array}{l}\text { Uji hipotesis parametrik Anova P Value } \geq \\
\alpha(\alpha=0,05)\end{array}$ \\
\hline $\begin{array}{l}\text { signifika } \\
\text { nsi }\end{array}$ & 0,048 \\
\hline $\begin{array}{l}\text { Interpreta } \\
\text { si }\end{array}$ & Berbeda signifikan \\
\hline
\end{tabular}

Berdasarkan hasil perhitungan pada Tabel 6 didapatkan bahwa sebaran skor pretes termasuk ke dalam normal dan postes termasuk ke dalam sebaran skor yang tidak normal, kemudian hasil uji homogenitas menunjukkan bahwa skor pretes dan postes termasuk homogen. Karena data tersebut tidak memenuhi syarat pengujian parametrik, sehingga untuk melakukan pengujian signifikansi menggunakan pengujian non parametrik (Mann-Whitney) berdasarkan hasil pengujian didapatkan nilai p-value (signifikansi) lebih kecil dari tingkat kepercayaan 95\% $(0,05)$ yakni sebesar 0,048 . Hal ini berarti pembelajaran inkuiri dengan metode eksperimen signifikan untuk meningkatkan KPS siswa.

\section{PEMBAHASAN}

Dari hasil penelitian yang sudah dilakukan di SDN 1 Aikmual dapat diambil kesimpulan bahwa pembelajaran menggunakan model inkuiri dan metode eksperimen dapat meningkatkan baik kemampuan kognitif maupun KPS siswa. Hal tersebut dapat dilihat dari hasil uji hipotesis yang menyatakan bahwa kedua variabel yang diteliti antara sebelum dan sesudah perlakuan terdapat perbedaan signifikan.

Adanya perbedaan signifikan pada kedua variabel yang diteliti tersebut dikarena proses pembelajaran yang dilakukan membuat siswa lebih mudah untuk mengerti mengenai konsep yang dipelajari dan keterampilan siswa pun dapat mengembangkan kemampuannya untuk melakukan percobaan karena belajaran 
menggunakan model inkuiri dengan metode eksperimen membuat pelajaran menarik bagi siswa. Ini sesuai dengan Adisyahputra (1992) bahwa salah satu kelebihan metode eksperimen adalah dapat membuat siswa lebih percaya atas kebenaran atau kesimpulan berdasarkan percobaannya sendiri daripada hanya menerima dari guru atau dari buku saja. Hal ini menyebabkan kemampuan kognitif dan KPS siswa meningkat. Model inkuiri yang digunakan juga membantu siswa dalam proses pembelajaran ini sesuai dengan penelitian Zacharia et al. (2008). Dia menyatakan bahwa melalui kegiatan eksperimen dengan model inkuiri dalam pembelajaran akan menghasilkan pengalaman interaktif yang didapatkan melalui proses yang dialami sendiri oleh siswa dalam melakukan eksperimen/praktikum. Sehingga berdampak padapeningkatan pemahaman konsep dan keterampilan proses sains siswa.

Selain siwa lebih yakin dengan hasil temuannya sendiri pembelajaran yang dilakukan dengan menggunakan model inkuiri dan metode eksperimen juga sesuai dengan psikologi anak Sekolah Dasar (SD). Hal ini diperkuat oleh pendapat Piaget dalam Arifin (2011) bahwa pada umur anak SD pembelajaran yang dilakukan harus bersifat nyata sehingga siswa dapat dengan mudah untuk menerima konsep/keterampilan yang diinginkan karena apa yang dilakukan adalah sesuatu yang dia rasakan langsung oleh siswa bukan merupakan sesuatu yang abstrak. Adisyahputra (1992) pun menyatakan bahwa kegiatan eksperimen memperkaya pengalaman siswa akan hal-hal yang bersifat objektif dan realistik.

Melalui pembelajaran yang dilakukan siswa mengembangkan kemampuan kognitif dan KPSnya dengan mengikuti sintak model inkuiri dan mereka pun melakukan eksperimen sendiri. Hal ini senada dengan yang sampaikan oleh Zachria dalam Saepuzaman (2011) yakni dengan metode eksperimen siswa secara total dilibatkan dalam melakukan sendiri, mengikuti suatu proses, mengamati suatu objek, menganalisis, membuktikan dan menarik kesimpulan sendiri tentang suatu objek, keadaan atau proses.
Pelajaran IPA bukan hanya pelajaran yang berisi fakta, data, konsep, hukum, postulat, dan lainnya. Namun, lebih dari itu pelajaran IPA hendaknya melatihkan kemampuan berpikir tingkat tinggi (kemampuan kognitif) pada siswa dan keterampilan proses sains (KPS). KPS merupakan merupakan bagian penting dari hakikat pelajaran IPA, karena pelajaran IPA bukan hanya pelajaran yang mengacu pada pengetahuan saja tetapi juga harus mengembangkan keterampilan proses dan sikap ilmiah siswa. Hal itu sesuai dengan Dahar (dalam Ismail, 2011) yang menyatakan bila seorang anak selama belajar sains hanya diberi informasi tentang sains yang sudah ada dengan cara mendengarkan penjelasan guru, maka sains itu sendiri akan berhenti berkembang. Pendapat ini diperkuat oleh pendapat Rustaman et al. (2005) yang mendefinisikan keterampilan proses sains sebagai keterampilan yang diperlukan untuk memperoleh, mengembangkan dan menerapkan konsep-konsep, prinsip-prinsip, hukum- hukum dan teori sains baik berupa keterampilan mental, keterampilan fisik maupun keterampilan sosial.

\section{SIMPULAN}

Pertama, efektivitas pembelajaran model inkuiri dengan metode eksperimen termasuk ke dalam kategori sedang baik untuk kemampuan kognitif maupun KPS siswa. Kedua, pembelajaran model inkuiri dengan metode eksperimen berpengaruh secara signifikan dalam meningkatkan kemampuan kognitif dan KPS siswa.

\section{DAFTAR PUSTAKA}

Adisyahputra, M.S.; Ernawati.; dan Zachrias A.H. (1992). Strategi Belajar Mengajar IPA. Jakarta: Departemen Pendidikan dan Kebudayaan.

Arifin, Zainal. (2011). Konsep dan Model

Pengembangan Kurikulum.

Bandung: PT Remaja

Rosdakarya.

Dahar, R Wilis. (1989). Teori-teori Belajar. Jakarta: Erlangga. 
Depdiknas. (2006). Kurikulum Tingkat Satuan Pendidikan Sekolah Dasar. Jakarta: Depdiknas

Dhewi, Rochman, Y. (2005). Efektivitas Metode Eksperimen dalam Meningkatkan Pemahaman Siswa Kelas 3 SMP pada Konsep Rangkaian Hambatan Listrik. Tesis SPs UPI Bandung:

Tidak diterbitkan.

Elianur, Rosita. (2011). Indonesia Peringkat 10 Besar Terbawah dari 65 Negara Peserta PISA. [online].

Tersedia: .kompasiana.com/post/read/33846 4/3/indonesia- peringkat-10besar- terbawah-dari-65-negarapeserta- pisa.html (21 April 2011)

Gulo, W. (2002). Strategi Belajar Mengajar. Jakarta: PT Gramedia Widiasarana Indonesia

Hake, R. R. (1998). Interactive Engagement Methods In Introductory Mechanics Courses. Departement of Physics, Indiana University, Bloomingtoon. [Online].Tersedia: http://www.physics.indiana.edu/ sdi/I E M-2b.pdf. [7 Desember 2007]

Ismail, A. (2011). Model Pembelajaran Children Learning In Science (Clis), Keterampilan Proses Sains, Penguasaan Konsep, Multimedia Dan Pokok Bahasan Fluida. Tesis SPs UPI Bandung: Tidak diterbitkan

Panggabean, L. P. (1996). Penelitian Pendidikan. Bandung: Jurusan Pendidikan Fisika FPMIPA UPI

Puskur. (2007). Kajian Kebijakan Kurikulum Mata Pelajaran IPA. Jakarta Depdiknas

Putri, S. (2014). PENGEMBANGAN DESAIN BLENDED LEARNING UNTUK PROGRAM PELATIHAN PENDALAMAN MATERI IPA BERBASIS KEBUTUHAN MAHASISWA

PGSD. Mimbar Sekolah Dasar, 1(2), 153160. Rustaman, N. Y., Dirdjosoemarto, S., Yudianto. A. S., Achmad, Y.,
Subekti, R., Rochintawati, D., Nurjhani, M. (2005). Strategi Belajar Mengajar Biologi. Malang : UM Press

Saepuzaman, D. (2011). Penerapan Model Pembelajaran Inkuiri Dengan Kombinasi Eksperimen NyataVirtual Pada Materi Rangkaian Listrik Arus Searah Untuk Meningkatkan Penguasaan Konsep Dan Keterampilan Proses Sains Siswa Sma. Tesis pada SPs UPI Bandung: Tidak diterbitkan

Wuryastuti, Sri. (2008). "Inovasi Pembelajaran IPA di Sekolah Dasar". Jurnal, Pendidikan Dasar, 9.

Zacharia, Z. C., Olympiou, G., \& Papaevripidou, M. (2008). "Effects of experimenting with physical and virtual manipulatives on students' conceptual understanding in heat and temperature". Journal of Research in Science Teaching, 45, (9), $1021-1035$. 